J. Product. \& Dev., 14(3): 673-681(2009)

\title{
EFFECT OF SOME PHYSICAL FACTORS ON LIPASE PRODUCTION BY SOME SELECTED FUNGI
}

\author{
A.M.A. Mansour*; F.S. El-Ashhab ${ }^{* * *}$ and O. M. El-Sheibani**** \\ Plant Production Department, Agriculture Faculty, Garyounis University, \\ Benghazi, Libya. \\ ** Chemistry Department, Science Faculty, Garyounis University, Benghazi, Libya. \\ **:* Botany Department, Science Faculty, Garyounis University, Benghazi, Libya.
}

\begin{abstract}
:
Seven fungi have been experimentally screened to get the most active two lipase producers. The experimental conditions were Czapek's yeast extract tributyrin emulsion (CYET) liquid medium, incubated at $30{ }^{\circ} \mathrm{C} \& \mathrm{pH} 5.0$ for 8 days.

Classical kinetic technique of enzymatic analysis has been used to study the effect of physical factors ( $\mathrm{HH}$, temperature \&incubation period). Optimal yield of lipase produced by Aspergillus niger after 8 days of incubation at $30{ }^{\circ} \mathrm{C} \& \mathrm{pH} 5.0$, while optimal yield of lipase produced by Rhizopus nigricans after 6 days of incubation at $30^{\circ} \mathrm{C} \& \mathrm{pH} 6.0$.

Conclusively, from this study, it could be concluded that the optimal yield of lipase was produced by Aspergillus niger at $\mathrm{pH} 5$ and $30{ }^{\circ} \mathrm{C}$ for 8 days incubation, while the optimal yield of lipase produced by Rhizopus nigricans at $\mathrm{pH} 6$ and $30{ }^{\circ} \mathrm{C}$ for 6 days incubation.
\end{abstract}

Keywords: Some physical factors, lipase production, some selected fungi

\section{INTRODUCTION:}

The importance of lipases in industrial processes has been throughly discussed in review articles (Rattary, 1984 and Yamane, 1987). Use of these enzymes in production of food flavors has been well documented (Nelson, 1972; Dwivedi, 1973; Arnold et al., 1975 and Shahani et al., 1976).

With the advent of biotechnology, fermentation processes have been employed to produce a wide variety of lipases from microbial sources (Kamimura et al., 2001; Elibol and Ozer, 2000). Molds have produced lipase, and the nature of the enzymes varies among species (Fukumoto et al., 1963; Iwai et al., 1964; Jensen, 1974; Kinsella and Hwang, 1976; Chander et al., 1980 \& 
1981; Fodiloglu and Erkmen, 1999 and Kader et al., 2007). Enzyme- producing microorganisms include bacteria (Kulkarni and Gadre, 2002; Babu et al., 2006), yeast (Corzo and Revah, 1999) and actinomycetes ( Sommer et al., 1997).

Lipases from microorganisms have drawn much attention especially for their potential use in biotechnology, mainly due to their availability and stability (Ghosh et al., 1996 and Wang et al., 1995).

Microbial enzymes that have been used to generate cheese flavors from milkfat have also been discussed by Jolly\& Kosikowski (1973); Huang \& Dooly (1976); Sood \& Kosikowski (1979); Arbige et al. (1986) and Omar et al. (1986).

The objective of the present work was to potentially characterize the effect of some physical factors on lipase production by some selected fungi, and to use these organisms as natural and economical source of the enzyme.

\section{MATERIALS AND METHODS}

\section{Organisms:}

Seven fungi (Aspergillus niger, Aspergillus oryzae, Fusarium oxysporium, Penicillium italicum, Rhizopus nigricans, Rhizoctonia solani \& Trichoderma viridae) obtained from National Collection of Yeast Cultures (NCYC), Agric. Res. Counsel, food Res. Inst., Colney lane Norwich. These cultures were maintained with periodic transfer on Czapek's yeast extract tributyrin agar slant.

\section{Growth medium:}

Fungal spores were grown in a sterilized $\left(121^{\circ} \mathrm{C} / 15 \mathrm{~min}\right)$ growth medium composed of (\%): 3 sucrose; $0.3 \mathrm{NaNO}_{3} ; 0.1 \mathrm{KH}_{2} \mathrm{PO}_{4} ; 0.05 \mathrm{MgSO}_{4} .7 \mathrm{H}_{2} \mathrm{O} ; 0.001$ $\mathrm{FeSO}_{4} .7 \mathrm{H}_{2} \mathrm{O} ; 0.1$ yeast extract, and $1 \mathrm{ml}$ of tributyrin emulsion.

\section{Production of lipase:}

Fungal organisms were inoculated into $40 \mathrm{ml}$ of the growth liquid medium in $250 \mathrm{ml}$ Erlenmyer flasks at the rate of $3 \mathrm{ml}$ spore suspension. Then incubated at $30{ }^{\circ} \mathrm{C}$ for 8 days for the production of lipase. Mycelium was separated by filtration then centrifugation at $5000 \mathrm{x}$ g for $20 \mathrm{~min}$.

The cell- free extract was the source of lipase enzyme. Lipase production was determined by the method of Fukumoto et al.(1963) with some modifications. The reaction mixture contained $3 \mathrm{ml}$ of the substrate (olive oil for lipase production); $1 \mathrm{ml}$ of $0.1 \mathrm{M}$ acetate buffer ( $\mathrm{pH} \mathrm{5.6);} 1 \mathrm{ml}$ of $0.2 \mathrm{M} \mathrm{CaCl}_{2}$, and $1 \mathrm{ml}$ of the enzyme solution to be tested.

The mixture was incubated at $30{ }^{\circ} \mathrm{C}$ for $150 \mathrm{~min}$. with constant shaking in calibrated water bath. At the end of incubation, the reaction mixture was mixed with $10 \mathrm{ml}$ ethanol (90\%) in a beaker to stop the reaction, and the free fatty acids formed by the enzyme reaction was titrated with $0.05 \mathrm{M} \mathrm{KOH}$ using a 
potentiometer titrator. The activities of lipase enzyme were expressed in terms of units, one unit being defined as one $\mathrm{ml}$ of the difference between the volume of the alkali solution consumed for titrating the test solution and the blank containing boiled enzyme.

\section{Measurement of growth:}

The dry weight of mycelium was measured by filtration of the cell culture through Whatman $\mathrm{N}^{\mathrm{o}} 1$ filter paper, washing with distilled water, and drying in an oven at $90{ }^{\circ} \mathrm{C}$ for $24 \mathrm{hr}$.

\section{RESULTS AND DISCUSSION}

\section{Screening of lipolytic activity of the fungi:}

Among seven fungi, those were screened for lipase production under the same experimental conditions the most active two organisms which produce high amount of lipase were Aspergillus niger and Rhizopus nigricans followed by Aspergillus oryzae (Table 1), while the other four fungi produced small amounts of the enzyme under these conditions and medium composition.

Table 1. Screening of lipolytic microorganisms ${ }^{\text {a }}$

\begin{tabular}{lcc}
\hline Organisms & $\begin{array}{c}\text { Wt. of biomass } \\
\text { mg mycelium/ml medium }\end{array}$ & $\begin{array}{c}\text { Lipase activity }^{\text {b }} \\
(\boldsymbol{\mu m o l e s ~ F F A ) ~}\end{array}$ \\
\hline Aspergillus niger & 120.30 & 1.000 \\
Aspergillus oryzae & 73.30 & 0.150 \\
Fusarium oxysporium & 9.45 & 0.125 \\
Penicillium italicum & 82.90 & 0.150 \\
Rhizopus nigricans & 22.13 & 0.350 \\
Rhizoctonia solani & 94.28 & 0.025 \\
Trichoderma viridae & 20.35 & 0.050 \\
\hline
\end{tabular}

a. Average of four trials.

b. Lipase activity is expressed as $\mu$ moles of free fatty acids liberated by $1 \mathrm{ml}$ of medium.

\section{Influence of physical factors on the production of lipases:}

Because of the higher lipase production Aspergillus niger and Rhizopus nigricans were selected for further physical studies.

\section{Incubation period:}

Out of five different periods, namely 2,4,6,8, and 10 days, the maximum amount of lipase was produced by Aspergillus niger and Rhizopus nigricans after 8,6 days respectively, (Table 2). Thus it is considered as optimum incubation period for these fungi were grown in Czapek's medium in stationary culture. The obtained optimum incubation period for Aspergillus niger was 8 days, while the 
Table 2. Effect of incubation period on lipase production by Aspergillus niger and Rhizopus nigricans ${ }^{\text {a }}$

\begin{tabular}{lcccc}
\hline \multirow{2}{*}{$\begin{array}{l}\text { Incubation } \\
\text { period } \\
\text { (days) }\end{array}$} & \multicolumn{2}{c}{ Aspergillus niger } & \multicolumn{2}{c}{ Rhizopus nigricans } \\
\cline { 2 - 5 } & $\begin{array}{c}\text { Wt. of biomass } \\
\text { mg mycelium/ } \\
\text { ml medium }\end{array}$ & $\begin{array}{c}\text { Lipase activity }^{\mathbf{b}} \boldsymbol{~}_{\boldsymbol{\mu m o l e s ~ F F A ) ~}} \\
\begin{array}{l}\text { Wt. of biomass } \\
\text { mg mycelium/ } \\
\text { ml medium }\end{array}\end{array}$ & $\begin{array}{c}\text { Lipase activity }^{\mathbf{b}} \\
(\boldsymbol{\mu m o l e s ~ F F A )}\end{array}$ \\
\hline $\mathbf{2}$ & 114.07 & 0.150 & 19.88 & 0.175 \\
$\mathbf{4}$ & 174.23 & 0.200 & 117.58 & 0.250 \\
$\mathbf{6}$ & 127.95 & 0.250 & 105.38 & 0.350 \\
$\mathbf{8}$ & 104.96 & 0.900 & 67.73 & 0.300 \\
$\mathbf{1 0}$ & 101.13 & 0.450 & 63.60 & 0.125 \\
\hline
\end{tabular}

a. Average of four trials.

b. Lipase activity is expressed as $\mu$ moles of free fatty acids liberated by $1 \mathrm{ml}$ of medium.

one observed by Chander et al, (1980) was 5 days for Aspergillus wentii, while Vaidehi and Jagadamba (1984) found that it was 6 days for Aspergillus flavus. The difference between these incubation periods could be due to the type of Aspergillus species (A. niger, A. wentii, A. flavus) and the composition of growth media used by different mentioned researchers.

In studying Fusarium oxysporium and Rhizoctonia solani Vaidehi and Jagadamba (1984) found that it was 8 days.

The observed optimum incubation period for Rhizopus nigricans (6 days) was in good agreement with Chander et al. (1981) observations for the same organism grown on yeast dextrose medium. Ogendero (1980) showed that Humicola grisea var. themoidea and Mucor pusillus produced the maximum amount of lipase on 6 days, while the optimum incubation period for Talaromyces thermophilus and Termoascus crustaceus was 8 days.

\section{Incubation temperature:}

Five different incubation temperatures, $20,25,30,35$, and $40{ }^{\circ} \mathrm{C}$ were tested under the previously mentioned optimum incubation period for each fungus. The maximum production of lipase was found at $30{ }^{\circ} \mathrm{C}$ (Table 3). These results are in excellent agreement with those obtained by Fukumoto et al.(1963) and Chander et al.(1981) for Aspergillus niger and Rhizopus nigricans, respectively.

Confirmation can be obtained by Chander et al. (1980), Eitenmeller et al. (1970), and Chander et al.(1977) for Aspergillus wentii, Penicillium roqueforti, and Penicillium chrysogenum respectively, with different incubation periods. Nevertheless, maximum amount of lipase production at $30-45^{\circ} \mathrm{C}$ were also 
Table 3. Effect of incubation temperature on lipase production by Aspergillus niger and Rhizopus nigricans ${ }^{\text {a }}$

\begin{tabular}{|c|c|c|c|c|}
\hline \multirow{2}{*}{$\begin{array}{l}\text { Incubation } \\
\text { temperature } \\
\left({ }^{\circ} \mathbf{C}\right)\end{array}$} & \multicolumn{2}{|c|}{ Aspergillus niger } & \multicolumn{2}{|c|}{ Rhizopus nigricans } \\
\hline & $\begin{array}{l}\text { Wt. of biomass } \\
\text { mg mycelium/ } \\
\text { ml medium }\end{array}$ & $\begin{array}{l}\text { Lipase activity } \\
(\mu \text { moles FFA) }\end{array}$ & $\begin{array}{l}\text { Wt. of biomass } \\
\text { mg mycelium/ } \\
\text { ml medium }\end{array}$ & $\begin{array}{l}\text { Lipase activity } \\
(\mu \text { moles FFA })\end{array}$ \\
\hline 20 & 103.32 & 0.175 & 95.55 & 0.200 \\
\hline 25 & 115.83 & 0.350 & 123.13 & 0.250 \\
\hline 30 & 119.10 & 0.875 & 94.33 & 0.350 \\
\hline 35 & 136.15 & 0.300 & 91.80 & 0.150 \\
\hline 40 & 138.58 & 0.300 & 92.09 & 0.100 \\
\hline
\end{tabular}

a. Average of four trials.

b. Lipase activity is expressed as $\mu$ moles of free fatty acids liberated by $1 \mathrm{ml}$ of medium.

observed by Liu et al.(1972) and Somkuti \& Bable (1969) for other fungi, Humicola lanuginose and Mucor pusillus, respectively.

\section{Starting $\mathrm{pH}$ values:}

The growth medium was adjusted to $\mathrm{pH} 4,5,6,7$ and 8. Maximum lipase was produced at $\mathrm{pH} 5.0$ by Aspergillus niger and 6.0 by Rhizopus nigricans (Table 4).

Table 4. Effect of starting $\mathrm{pH}$ on lipase production by Aspergillus niger and Rhizopus nigricans ${ }^{\text {a }}$

\begin{tabular}{lcccc}
\hline & \multicolumn{2}{c}{ Aspergillus niger } & \multicolumn{2}{c}{ Rhizopus nigricans } \\
\cline { 2 - 5 } $\begin{array}{c}\text { Starting } \\
\text { pH }\end{array}$ & $\begin{array}{c}\text { Wt. of biomass } \\
\text { mg mycelium/ } \\
\text { ml medium }\end{array}$ & $\begin{array}{c}\text { Lipase } \\
\text { activity } \\
(\boldsymbol{\mu m o l e s} \\
\text { FFA) }\end{array}$ & $\begin{array}{c}\text { Wt. of biomass } \\
\text { mg mycelium/ } \\
\text { ml medium }\end{array}$ & $\begin{array}{c}\text { Lipase activity }^{\mathbf{b}} \\
(\boldsymbol{\mu m o l e s ~ F F A ) ~}\end{array}$ \\
\hline $\mathbf{4}$ & 118.78 & 0.225 & 78.00 & 0.300 \\
$\mathbf{5}$ & 119.10 & 0.875 & 94.33 & 0.350 \\
$\mathbf{6}$ & 118.23 & 0.375 & 141.95 & 0.550 \\
$\mathbf{7}$ & 109.38 & 0.175 & 118.23 & 0.450 \\
$\mathbf{8}$ & 105.10 & 0.150 & 114.93 & 0.150 \\
\hline
\end{tabular}

a. Average of four trials.

b. Lipase activity is expressed as $\mu$ moles of free fatty acids liberated by $1 \mathrm{ml}$ of medium.

These results agree with findings of Fukumoto et al. (1963) with Aspergillus niger and with findings of Chander et al.(1977, 1980 and 1981) and 
Hosono et al.(1973)who demonstrated maximum yield of lipase by Rhizopus nigricans, Aspergillus wentii, Penicillium chrysogenum and Candida muscorum, respectively at $\mathrm{pH} 6.0$. On contrary, higher $\mathrm{pH}$ optima was noted in Penicillium camemberti and Gleosporium olvarium (Dolezalek and Minarik, 1969 and Grasas, 1973).

Conclusively, from this study, it could be concluded that the optimal yield of lipase was produced by Aspergillus niger at $\mathrm{pH} 5$ and $30{ }^{\circ} \mathrm{C}$ for 8 days incubation, while the optimal yield of lipase produced by Rhizopus nigricans at $\mathrm{pH} 6$ and $30^{\circ} \mathrm{C}$ for 6 days incubation.

\section{REFERENCES}

Arbige, M. V.; Freund, P. R.; Silver, S.C. and Zelco, J. T. (1986). Novel lipase for Cheddar cheese flavor development. Food Technology, 40:91.

Arnold, R. G.; Shahani, K. M. and Dwivedi, B. K. (1975). Application of lipolytic enzymes to flavor development in dairy products. Journal of Dairy Science, 58:1127.

Babu, J.; Pramod, W. R. and Pa Ashok, K. (2006). Studies on the enhanced production of extracellular lipase by Staphylococcus epidermidis. Journal of Gen. Applied Microbiology, 52: 315

Chander, H.; Sannabhadti, S. S.; Elias, J. and ranganathan, B. (1977). Factors affecting lipase production by Penicillium chrysogenium. A Research Note, Journal of Dairy Science, 42: 1677.

Chander, H.; Batish, V. K.; Sannabhadti, S. S. and Sirinivasan, R. A. (1980). Factors affecting lipase production in Aspergillus wentii. Journal of food Science, 45: 598.

Chander, H.; Batish, V. K.; Ghodekar, D. P. and Sirinivasan, R. A. (1981). Factors affecting lipase production in Rhizopus nigricans. Journal of Dairy Science, 64: 193.

Corzo, R. and Revah, S. (1999). Production and characteristics of the lipase from Yarrowia lipolytica 681. Bioresource Technology, 70: 173.

Dolzalec, J. and Mminarik, R.(1969). Effect of $\mathrm{pH}$ of the medium and of rennet on enzymatic activity of the mold Penicillium camemberti. Sk. Chm. Technology, Praze, E, 20: 67.

Dwivedi, B. K.(1973). The role of enzymes in food flavors. Part I; Dairy products. Rev. Food Science Technology,. 3:457.

Eitenmeller, R. R.; Vakil, J. R. and Shahani, K. M. (1970). Production and properties of Penicillium roqueforti lipase. Journal of Food Science, 35:130. 
Elibol, M. and Ozer, D. (2000). Influence of oxygen transfer on lipase production by Rhizopus arrizus. Proceeding of Biochemistry, 36: 325.

Fodiloglu, S. and Erkmen, O. (1999). Lipase production by Rhizopus oryzae growing on different carbon and nitrogen sources. Journal of Science Food Agri., 79: 1936.

Fukumoto, J.; Iwai, M. and Tsujisaka, Y. (1963). Studies on lipase. I. purification and crystallization of lipase secreted by Aspergillus niger. Journal of Gen. Applied Microbiology, 10:13.

Ghosh P. K.; Saxena, T. K.; Gupta, R.; Yadav, R. P. and Davidson, S. (1996). Microbial lipases: Production and Application. Science Prog., 79: 119.

Grasas, Y. A. (1973). Lipase from Gleosporium olivarium. Aceites, 23: 432.

Hosono, A.; Otani, H. and Tokita, F. (1973). Isolation, identification and some properties of lactose utilizing yeasts. Jap. Journal of Dairy Science, 22: 114.

Huang, H. T. and Dooly, J. G. (1976). Enhancement of cheese flavors with microbial esterases. Biotech. Bioeng.,18: 909.

Iwai, M.; Tsujisaka, Y. and Fukumoto, J. (1964). Studies on lipase. II. Hydrolytic and esterifying actions of crystalline lipase of Aspergillus niger. Journal of Gen. Applied Microbiology, 10:13.

Jensen, R. G. (1974). Characteristics of lipase from mold Geotrichum candidum. A review. Lipids, 9: 149

Jolly, R. C. and Kosikowski, F. V. (1973). Flavor and chemical changes in blue cheese by microbial lipases Journal of Dairy Science, 56: 624.

Kader, R.; Yousuf, A. and Hoq, M. M. (2007). Optimization of lipase production by Rhizopus MR12 in shake culture. Journal of Applied Science, 7: 855 .

Kamimura, E. S.; Medieta, O.; Rodrigues, M. I. and Maugeri, F. (2001). Studies on lipase-affinity adsorption using response-surface analysis. Biotechnolog of Applied Biochemistry, 33: 153.

Kinsella, J. E. and Hwang, D. H. (1976). Enzymes of Penicillium roqueforti involved in the biosynthesis of cheese flavor. Rev. Food Sci. Technol., 8: 191.

Kulkarni, N. and Gardre R. V. (2002). Production and properties of an alkaline, thermophilic lipase from Pseudomonas fluorescens NS2W. Journal of Industrial Microbiology Biotechnology, 28: 344.

Liu, W. H.; Beppo, T. and Arima, K. (1972). Cultural conditions and some properties of the lipase of Hemicola lanuginose S-38. Agriculture of Biololgy Chem., 37: 1919. 
Nelson, J. H. (1972). Enzymatically produced flavors of fatty systems. JAOCS, 49: 559.

Ogundero, V. W. (1980). Lipase activities of thermophilic fungi from mouldy groundnuts in Nigeria. Mycologia., 72: 118.

Omar, M. M.; El-zayat, A. I. and Ashore, M. (1986). Flavor enhancement by lipase addition of Ras cheese made from reconstituted milk. Food Chem. ,19: 277.

Rattary, J. B. M. (1984). Biotechnology and the fats and oils industry. An Overview, JAOCS, 61: 1701.

Shahani, K. M.; Arnold, R. G.; Kilara, A. and Dwivedi, B. K. (1976). Role of microbial enzymes in flavor development in foods. Biotech. Bioeng., 18: 891.

Somkuti, G. A. and Babel, F. J. (1969). Lipase of Mucor pusillus. Appl. Microbiol. 17: 606.

Sommer, P.; Bormann, C. and Gotz, F. (1997). Genetic and biochemical characterization of a new extracellular lipase from Streptomyces cinnamomeus. Appl. Environ. Microbiol., 63: 3553.

Sood, V. K. and Kosikowski, F. V. (1979). Process Cheddar cheese from plain and enzyme treated retentates. Journal of Dairy Science, 62: 1713.

Vaidehi, B. K. and Jagadamba, G. V. (1984). Lipase activity of some fungi isolated from groundnut. Current Science, 53: 1253.

Wang, Y.; Srivastava, K. C.; Shen, G. J. and Wang, H. Y. (1995). Thermostable alkaline lipase from a newly isolated thermophilic Bacillus strain, A30-1(ATCC 53841). Journal of Ferment. Bioeng., 79: 433.

Yamane, T. (1987). Enzyme technology for lipids industry. An engineering overview, JAOCS, 64: 1657. 
تأثير بعض العوامل الفيزيائية على انتاج بعض الفطريات لانزيم الليبيز

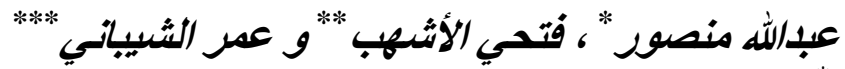

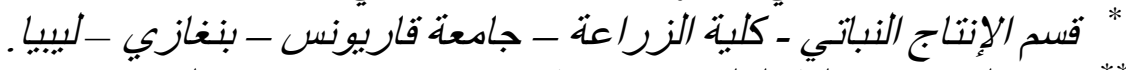

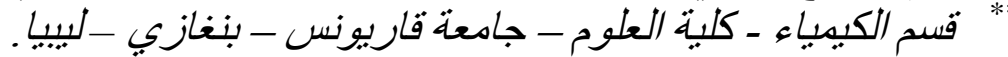

$$
\begin{aligned}
& \text { ***** قسم النبات ـ كلية العلوم - جامعة قاريونس - بنغازي - ليييا. }
\end{aligned}
$$

تم انتخاب سبعة فطريات مختلفة لتحديد افضلها انتاجا لإنزيم الليبيز باستخدام

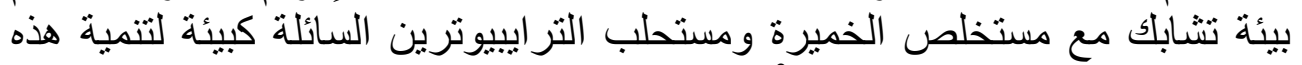

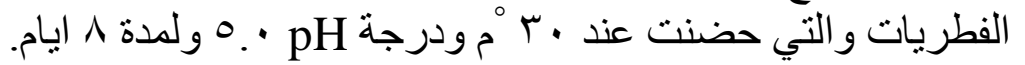
وجد ان اعلى انتاج لانزيم الليبيز كان عن طريق فطر ماند

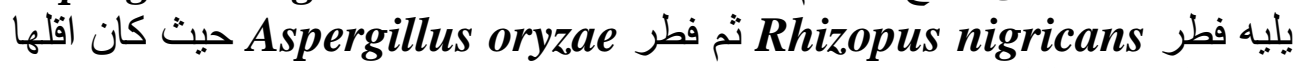
Rhizopus ، Aspergillus niger انتاجا للانزيم. لذللك فقد استخدمت فطريات nigricans

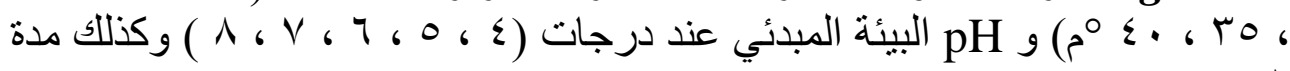

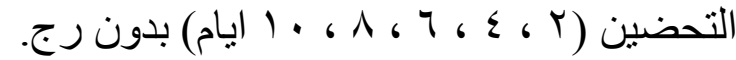

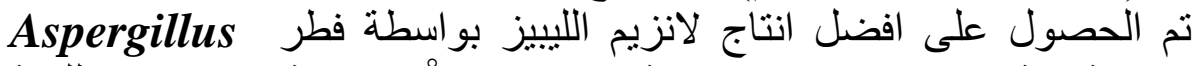

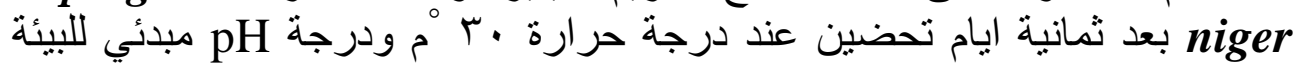
عند

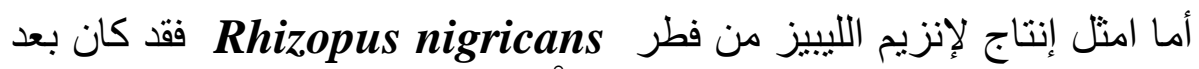

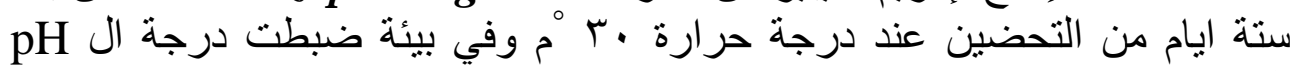

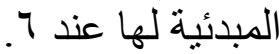

